\title{
Maya Index Analysis of Dengue Fever Vector in East Metro Sub-District Lampung Province Indonesia
}

\author{
Betara Sona*, Emantis Rosa, M. Kanedi, Tugiyono \\ Jurusan Biologi FMIPA Universitas Lampung \\ J. Soemantri Brojonegoro, Gedong Meneng, Bandar Lampung, 35145, Lampung, Indonesia \\ *E-mail : betara.sona@gmail.com
}

\begin{abstract}
Dengue fever was one of the dangerous diseases due to it might cause death in a short time. It transmitted through its vectors, namely, Aedes aegypti and Aedes albopictus. Maya index is an indicator that used to identify a high-risk area or not as a breeding ground for Aedes sp. The purpose of this study was to determine the type of landfill which has the potential as a breeding ground for mosquitoes, to find out the larvae found in various landfill sites, and to know the Maya index status in Metro Timur Subdistrict which was carried out in November-December 2017. This research conducted by a direct survey of 100 residents' houses in East Metro. The results indicated that the type of controlled water reservoir that had the most potential as a breeding place for mosquitoes was a bathtub, while the type of water reservoir that was not controlled which had the potential as a place for mosquito breeding was a fish pond usage. There were 2 types of larvae found, namely, Aedes aegypti larvae with a percentage of $47.7 \%$ and Aedes albopictus larvae with a percentage of $52.3 \%$. The Maya index status detected there, was a medium category, which obtained from the BRI combination and HRI category. Besides, it did not mean that the area has been free from dengue cases. The role of the community is still very much needed in eradicating landfills which has the potential as a breeding place for dengue mosquitoes vector.
\end{abstract}

Keywords: maya index, dengue fever, larva of Aedes sp.

\section{PENDAHULUAN}

DBD (Demam Berdarah Dengue) merupakan penyakit yang diakibatkan oleh virus yang dapat menyebabkan kematian dalam waktu yang sangat singkat. Vektor utama DBD ialah nyamuk Aedes aegypti, sedangkan vektor potensialnya ialah Aedes albopictus (Natadisastra, 2009).

Di Provinsi Lampung, kasus DBD terjadi di beberapa kota dan kabupaten, antara lain di kota Metro. Kota Metro merupakan salah satu daerah endemis DBD dengan kasus yang cukup tinggi. Kasus DBD tersebar di 22 kelurahan dari 5 kecamatan yang ada di Kota Metro. Pada tahun 2015, Kecamatan Metro Timur mempunyai kasus DBD tertinggi dengan jumlah 96 kasus dan Kecamatan Metro Selatan mempunyai kasus DBD terendah dengan jumlah 10 kasus (Dinas Kesehatan Kota Metro, 2015). Beberapa tahun terakhir kasus DBD di Kota
Metro cenderung fluktuatif, namun harus tetap perlu dilakukan penanganan serius.

Salah satu cara yang dapat dilakukan dalam upaya membantu penanggulangan kasus DBD, yaitu dengan melakukan analisis tempat perindukan yang berisiko tinggi melalui analisis maya index.

Berbagai upaya telah dilakukan dalam upaya penanggulangan DBD namun hasilnya masih kurang optimal yang ditandai dengan masih ditemukannya kasus DBD dari tahun ke tahun (Nahla, 2009). Maya index digunakan untuk mengidentifikasi suatu area yang berisiko tinggi sebagai tempat perkembangbiakan (breeding site) nyamuk Aedes sp. didasarkan pada status kebersihan lingkungan HRI (Hygiene Risk Indikator) dan ketersediaan tempat-tempat yang mungkin berpotensi sebagai tempat perkembangbiakan nyamuk BRI (Breeding Risk Index) (Satoto, 2005). Dengan diketahuinya maya index suatu daerah, diharapkan dapat memberikan informasi 
yang tepat dan akurat dalam upaya penanggulangan kasus DBD khususnya di Kecamatan Metro Timur.

Penelitian ini bertujuan untuk mengetahui jenis TPA yang berpotensi sebagai tempat perindukan nyamuk, mengetahui larva yang ditemukan di berbagai TPA, dan mengetahui status maya index di Kecamatan Metro Timur.

\section{METODE PENELITIAN}

Penelitian ini dilaksanakan pada bulan November sampai dengan Desember 2017. Pengambilan sampel dilaksanakan di Kecamatan Metro Timur, Provinsi Lampung dan identifikasi larva dilaksanakan di Laboratorium Zoologi Jurusan Biologi Fakultas Matematika dan IImu Pengetahuan Alam Universitas Lampung.

Penelitian ini menggunakan metode survei pada daerah endemis demam berdarah di Kecamatan Metro Timur. Pengamatan secara langsung dilaksanakan di 100 rumah warga. Hasil penelitian dipaparkan dalam bentuk deskriptif yang menggambarkan dan menjelaskan fakta indeks keberadaan larva nyamuk yang ditemukan pada berbagai tempat penampungan air baik yang masih terkontrol ataupun tidak terkontrol serta kategori maya index yang didasarkan pada indikator BRI (Breeding Risk Index) dan HRI (Hygiene Risk indikator). Pada masingmasing tempat penampungan air yang ditemukan positif larva diambil sampel larvanya untuk dilakukan identifikasi larva.

Analisis data dengan cara mengkombinasikan 2 indikator yaitu Breeding Risk Index (BRI) dan Hygiene Risk Indikator (HRI) yang nantinya dikategorikan menjadi rendah, sedang dan tinggi dengan menggunakan perhitungan distribusi tertinggi. BRI yang rendah menunjukkan bahwa hanya terdapat sedikit contralable sites dan memiliki resiko rendah untuk terjadi perkembangbiakan larva dan begitu pula sebaliknya. HRI yang rendah menunjukkan bahwa terdapat sedikit jumlah disposable sites yang termasuk dalam kategori kotor. Nilai BRI dan HRI di setiap rumah disusun dalam matriks $3 \times 3$ untuk menentukan kategori maya index rendah, sedang dan tinggi (Supartha, 2008).

\section{HASIL DAN PEMBAHASAN}

\section{Keadaan TPA yang berpotensi sebagai Tempat Perindukan Nyamuk di Keca- matan Metro Timur}

Hasil survei berbagai jenis tempat penampungan air yang dapat berpotensi sebagai tempat perindukan nyamuk dan jumlah tempat penampungan air yang ditemukan larva disajikan pada tabel 1.

Tabel 1. Jenis Kontainer dan Keberadaan Larva Aedes spp. pada 100 rumah warga di Kecamatan Metro Timur

\begin{tabular}{|c|c|c|}
\hline $\begin{array}{l}\text { Jenis Tempat } \\
\text { Penampungan Air }\end{array}$ & $\begin{array}{l}\text { Jumlah } \\
\text { Kontainer }\end{array}$ & $\begin{array}{l}\text { Jumlah } \\
\text { Kotainer } \\
\text { Positif Larva }\end{array}$ \\
\hline $\begin{array}{l}\text { Controllable } \\
\text { Container }\end{array}$ & 289 & 23 \\
\hline Ember & 8 & 1 \\
\hline Bak Mandi & 102 & 15 \\
\hline $\begin{array}{l}\text { Wadah } \\
\text { penampung air }\end{array}$ & 46 & 1 \\
\hline Gentong & 24 & 6 \\
\hline $\begin{array}{l}\text { Tempat Minum } \\
\text { Burung }\end{array}$ & 19 & 0 \\
\hline Dispenser & 14 & 0 \\
\hline Akuarium & 1 & 0 \\
\hline Kolam ikan & 2 & 0 \\
\hline $\begin{array}{l}\text { Disposable } \\
\text { Container }\end{array}$ & 51 & 21 \\
\hline $\begin{array}{l}\text { Wadah } \\
\text { penampung air } \\
\text { bekas }\end{array}$ & 5 & 4 \\
\hline Bak mandi bekas & 1 & 1 \\
\hline Ban bekas & 9 & 3 \\
\hline Akuarium bekas & 3 & 2 \\
\hline Ember bekas & 9 & 3 \\
\hline $\begin{array}{l}\text { Tempat minum } \\
\text { burung bekas }\end{array}$ & 1 & 1 \\
\hline Kolam bekas & 7 & 5 \\
\hline Kaleng bekas & 7 & 2 \\
\hline Botol bekas & 4 & 0 \\
\hline Pot bekas & 3 & 0 \\
\hline Drum bekas & 2 & 0 \\
\hline
\end{tabular}

Tabel 1. memperlihatkan jenis-jenis tempat penampungan air baik yang masih bisa dikontrol ataupun tidak dapat dikontrol yang berpotensi sebagai tempat perindukan nyamuk yang terdapat pada 100 rumah di Kecamatan Metro Timur pada bulan November 2017. Pada tempat penam- 
pungan air yang terkontrol (Controllable container), terdapat 81 ember namun yang ditemukan positif larva hanya ada 1 ember, dari 102 bak mandi ditemukan 15 yang positif larva, dari 46 bak air hanya ditemukan 1 bak air yang positif larva, dari 24 gentong ditemukan 6 gentong yang positif larva, kemudian dari 19 tempat minum burung, 14 dispenser, 1 akuarium, 2 kolam ikan, keseluruhannya tidak ditemukan adanya yang positif larva, sehingga dari 289 kontainer tempat penampungan air yang terkontrol, ditemukan 23 kontainer yang positif larva Aedes. Kontainer yang paling banyak ditemukan adanya larva Aedes yaitu bak mandi.

Sebagian besar bak mandi yang dijumpai adanya larva masih terbuat dari semen dan tanah berukuran besar. Hal ini berkaitan dengan ketersediaan makanan bagi jentik. Pada kontainer berbahan semen mikroorganisme yang menjadi bahan makanan larva lebih mudah tumbuh pada dindingnya dan nyamuk betina lebih mudah mengatur posisi tubuh pada waktu meletakkan telur, dimana telur secara teratur diletakkan di atas permukaan air, dibandingkan kontainer berbahan keramik dan plastik yang cenderung licin. Pada kontainer berbahan licin nyamuk betina tidak dapat berpegangan erat dan mengatur posisi tubuhnya dengan baik sehingga pada saat bertelur, telur disebarkan di permukaan air dan menyebabkan mati terendam sebelum menetas.

Penelitian ini sesuai dengan hasil penelitian Badrah dan Hidayah (2011) di Kabupaten Penajam Paser Utara mengenai hubungan antara tempat perindukan nyamuk Aedes aegypti dengan kasus DBD bahwa ada hubungan antara bahan kontainer dengan keberadaan jentik Aedes aegypti. Penelitian ini menemukan dari 340 kontainer yang diperiksa $86,7 \%$ kontainer berbahan semen dan $40 \%$ berbahan tanah positif jentik Aedes aegypti. Hasil ini juga selaras dengan bionomik nyamuk Aedes yang senang pada kelembaban tinggi dan takut sinar (photopobia).

Sedangkan pada tempat penampungan air yang tidak terkontrol (Disposable container), terdapat 5 wadah air bekas namun yang ditemukan positif larva hanya ada 4 wadah, dari 1 bak mandi bekas ditemukan positif larva, dari 9 ban bekas hanya ditemukan 3 ban yang positif larva, dari 3 akuarium bekas ditemukan 2 akuarium yang positif larva, dari 9 ember bekas ditemukan 3 ember yang positif larva, dari 1 tempat minum burung bekas ditemukan positif larva, dari 7 kolam bekas yang sudah tidak ada ikannya ditemukan 5 kolam yang positif larva, dari 7 kaleng bekas ditemukan 2 kaleng yang positif larva kemudian dari 4 botol bekas, 3 pot bekas, 2 drum bekas, keseluruhannya tidak ditemukan adanya yang positif larva, sehingga dari 51 kontainer tempat penampungan air yang sudah tidak terkontrol, ditemukan 21 kontainer yang positif larva Aedes. Kontainer tidak terkontrol yang paling banyak ditemukan adanya larva Aedes yaitu kolam bekas yang sudah tidak ada ikan didalamnya namun berisi air.

Tempat penampungan air yang ditemukan adanya larva tidak berhubungan secara langsung dengan tanah. Menurut Yotopranoto (1998), nyamuk Aedes tidak dapat berkembang biak di selokan, got, atau kolam yang keadaan airnya langsung berhubungan dengan tanah. Larva Aedes banyak ditemukan di tempat-tempat yang sudah tidak terkontrol seperti ban bekas, ember bekas, bak bekas, botol bekas, dll yang dapat menjadi tempat penampungan air pada saat hujan sehingga dapat menjadi tempat perkembangbiakan larva. Hal ini sejalan dengan artikel WHO (2009) yang menyebutkan bahwa di Asia dan Amerika Aedes aegypti berkembang biak dalam wadah buatan manusia seperti: kendi, besi beton, drum, sampah plastik bekas makanan, ban mobil bekas dan barang lainnya yang dapat menampung air hujan.

\section{Identifikasi Larva yang Ditemukan}

Hasil identifikasi larva yang ditemukan pada berbagai tempat penampungan air di Kecamatan Metro Timur dengan berpedoman pada buku kunci identifikasi larva Aedes, Ditjen PP \& PL (2008) disajikan pada tabel 2. Berdasarkan tabel 2. dapat dilihat bahwa jenis larva nyamuk Aedes yang ditemukan hanya ada 2 jenis, yaitu Aedes aegypti de-ngan persentase 47,7\% dan Aedes albopictus 52,3\%. 
Tabel 2. Hasil Identifikasi Larva

No Nama Spesies Persentase

$\begin{array}{lll}1 & \text { Aedes aegypti } & 47,7 \% \\ 2 & \text { Aedes albopictus } & 52,3 \%\end{array}$

Kategori Rumah berdasarkan Breeding Risk Index, Hygiene Risk Index, Dan Maya Index

Adapun berdasarkan hasil survey pada 100 rumah di Kecamatan Metro Timur, diperoleh kategori rumah berdasarkan Breeding Risk Index, Hygiene Risk Indikator, dan Maya Index dapat dilihat pada tabel 3.

Tabel 3. Kategori Rumah di Kecamatan Metro Timur Berdasarkan Breeding Risk Index, Hygiene Risk Index, dan Maya Index.

\begin{tabular}{lccc}
\hline Kategori & $\begin{array}{c}\text { Breeding } \\
\text { Risk Index } \\
(B R I)\end{array}$ & $\begin{array}{c}\text { Hygiene } \\
\text { Risk } \\
\text { Indikator } \\
(H R I)\end{array}$ & $\begin{array}{c}\text { Maya } \\
\text { Index } \\
(\text { MI) }\end{array}$ \\
\hline Rendah & 27 rumah & 0 & 24 rumah \\
\hline Sedang & 57 rumah & 95 rumah & 58 rumah \\
\hline Tinggi & 16 rumah & 5 rumah & 18 rumah \\
\hline Total & 100 & 100 & 100 \\
\hline
\end{tabular}

Tabel 3. memperlihatkan bahwa berdasarkan hasil survey pada 100 rumah di Kecamatan Metro Timur terdapat 27 rumah dengan kategori Breeding Risk Index rendah, 57 rumah dengan kategori Breeding Risk Index sedang, dan 16 rumah dengan kategori Breeding Risk Index tinggi. Kemudian berdasarkan Hygiene Risk Indikator, terdapat 95 rumah berkategori sedang, 5 rumah berkategori tinggi, namun tidak ditemukan adanya rumah yang berkategori rendah. Selanjutnya berdasarkan Maya Index, terdapat 24 rumah dengan kategori rendah, 58 rumah dengan kategori sedang, dan 18 rumah dengan kategori tinggi.

\section{Kategori Breeding Risk Index (BRI)}

Berdasarkan gambar 1 dapat dilihat bahwa jumlah rumah yang mempunyai Breeding Risk Index (BRI) dengan kategori tinggi sebesar 16\%, kategori sedang sebesar $57 \%$, dan kategori rendah sebesar $27 \%$. Jadi, dapat disimpulkan bahwa berdasarkan nilai BRI menunjukkan bahwa rumah di Kecamatan Metro Timur masuk dalam kategori Breeding Risk Index (BRI) sedang karena persentase rumah dalam kategori sedang paling tinggi dibandingkan rumah dengan kategori rendah dan tinggi yaitu dengan persentase $57 \%$.

Semakin tinggi nilai BRI di suatu daerah menunjukkan semakin banyak tempat penampungan air terkontrol yang dapat berpotensi sebagai tempat perindukan nyamuk Aedes spp. Menurut Supartha (2008), BRI yang rendah menunjukkan bahwa hanya terdapat sedikit kontainer yang berpotensi sebagai tempat perindukan nyamuk dan memiliki resiko rendah untuk terjadi perkembangbiakan larva nyamuk dan begitu pula sebaliknya.

\section{Persentase Kategori Breeding Risk Index}

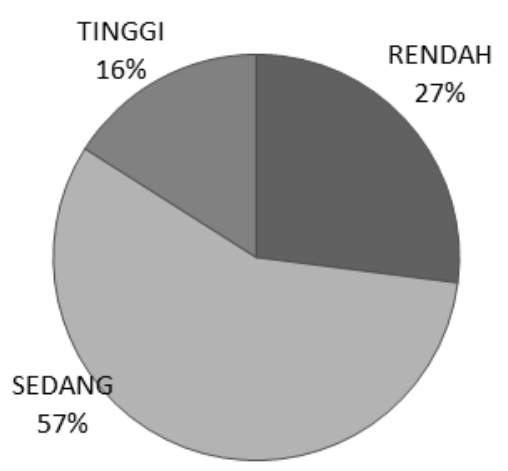

Gambar 1. Persentase kategori Breeding Risk Index pada 100 rumah di Kecamatan Metro Timur

Walaupun BRI di daerah Kecamatan Metro Timur masih dalam kategori sedang bukan berarti sudah bebas dari kasus demam berdarah. Kasus demam berdarah masih sangat memungkinkan terjadi di Kecamatan Metro Timur karena masih banyak ditemukan tempat penampungan air yang dapat dijadikan sebagai tempat perindukan nyamuk dan masih dijumpai adanya larva vektor utama dan vektor potensial dari 
demam berdarah, yaitu Aedes aegypti dan Aedes albopictus. Oleh karena itu, masyarakat tetap harus waspada dan melakukan pencegahan terhadap perkembangbiakan nyamuk. Hal ini sejalan dengan penelitian Joharina (2014) bahwa walaupun sebagian besar rumah mempunyai BRI kategori rendah, namun masyarakat tetap perlu memperhatikan lingkungan di sekitar rumah terutama pada musim penghujan yang berpotensi munculnya genangan air pada kontainer bekas yang berada di luar rumah.

\section{Kategori Hygiene Risk Indikator (HRI)}

Berdasarkan Gambar 2 dapat dilihat bahwa jumlah rumah yang mempunyai Hygiene Risk Index (HRI) dengan kategori tinggi sebesar $5 \%$, kategori sedang sebesar $95 \%$, dan tidak ada rumah yang berkategori HRI rendah. Jadi, dapat disimpulkan bahwa rumah di Kecamatan Metro Timur masuk dalam kategori Hygiene Risk Index (HRI) sedang karena persentase rumah dalam kategori sedang lebih tinggi dibandingakan rumah dalam kategori tingi, yaitu dengan persentase mencapai 95\% atau dengan kata lain status kebersihan di daerah tersebut masuk ke dalam kategori sedang. HRI sedang menunjukkan masih adanya tempat yang tidak terkontrol yang ditemukan di Kecamatan Metro Timur walaupun tidak banyak namun masih berpotensi sebagai tempat perindukan nyamuk. Tempat yang tidak dikontrol tersebut adalah tempat yang apabila tergenang air akan dapat menjadi tempat perkembangbiakan larva. Tempat tersebut di antaranya adalah botol bekas, ember bekas, ban bekas, drum bekas, bak air bekas, bak mandi bekas, tempat minum burung bekas, akuarium bekas, dll. Sesuai dengan pendapat Supartha (2008), HRI yang rendah menunjukkan bahwa terdapat sedikit jumlah kontainer tak terkontrol yang berpotensi sebagai tempat perindukan nyamuk yang termasuk dalam kategori kotor. Menurut Dhewantara (2012) Dinata (2012) Walaupun Hygiene Risk Index (HRI) di suatu daerah masih dalam kategori sedang namun daerah tersebut tetap potensial sebagai tempat perkembangbiakan nyamuk.

\section{Persentase Kategori Hygiene Risk Indikator}

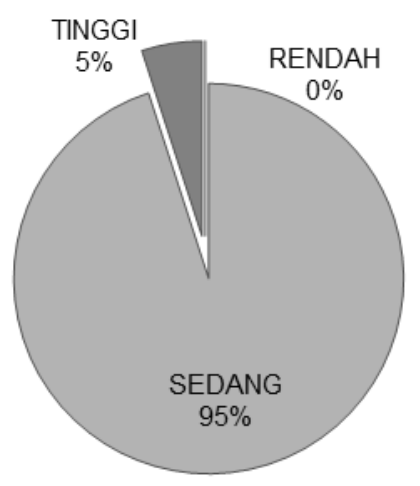

Gambar 2. Persentase kategori Hygiene Risk Indikator pada 100 rumah di Kecamatan Metro Timur

\section{Status Maya Index (MI)}

Status Maya Index (MI) berdasarkan kategori Breeding Risk Index (BRI) dan Hygiene Risk Index (HRI) dapat dilihat bahwa jumlah rumah yang mempunyai maya index dengan kategori rendah sebesar $24 \%$, kategori sedang sebesar $58 \%$, dan kategori tinggi sebesar 18\%. Jadi, dapat diartikan bahwa berdasarkan maya index menunjukkan bahwa rumah di Kecamatan Metro Timur termasuk dalam kategori sedang karena persentase rumah dalam kategori sedang paling tinggi, yaitu $58 \%$. Hal ini berarti resiko daerah tersebut dijadikan sebagai tempat perkembangbiakan nyamuk Aedes sp. masih dalam kategori sedang namun bukan berarti sudah bebas dari kasus DBD.

Menurut data Dinas Kesehatan, di Kecamatan Metro Timur kasus DBD masih tergolong tinggi yaitu terdapat 71 kasus yang tersebar di 5 kelurahan pada tahun 2016. Hal ini menunjukkan bahwa status maya index sedang juga sangat berisiko terhadap penularan DBD apabila masyarakat kurang memperhatikan tempattempat yang dapat berpotensi sebagai tempat perindukan nyamuk dan juga kebersihan lingkungan. Hal tersebut sesuai dengan penelitian Purnama (2012) ada hubungan antara status maya index dengan 
kejadian DBD. Status maya index tinggi memiliki risiko 3,088 kali dibandingkan dengan yang memiliki maya index rendah untuk terkena DBD. Walaupun maya index suatu daerah dalam kategori rendahsedang, tetapi jika masih terdapat kontainer yang positif jentik maka daerah tersebut menjadi potensial terkena DBD.

\section{Persentase Status Maya Index}

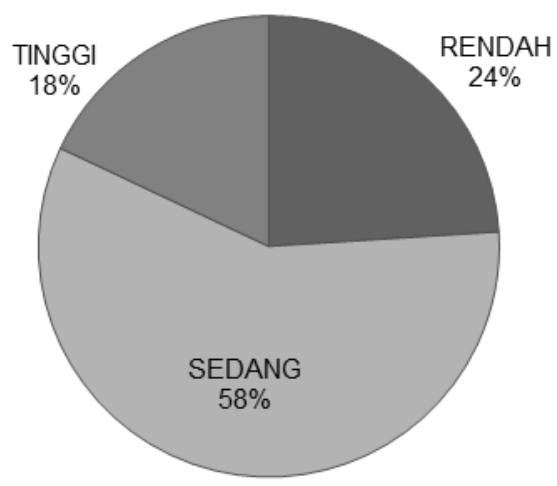

Gambar 3. Persentase status Maya Index pada 100 rumah di Kecamatan Metro Timur

Sikap masyarakat sangat berpengaruh terhadap kejadian DBD. Masih minimnya kepedulian masyarakat terhadap pemberantasan DBD di Kecamatan Metro Timur dapat menjadi faktor yang berpengaruh terhadap kejadian DBD. Hal tersebut terlihat dari masih adanya masyarakat yang tidak mau rumahnya diperiksa apakah positif jentik atau negatif jentik. Setiap kelurahan selalu memiliki rumah yang tidak dapat dimasuki untuk pemeriksaan jentik dengan alasan kamar mandi belum dibersihkan, juga dengan alasan rumah tersebut sudah bersih dan tidak terdapat jentik. Hal tersebut sesuai dengan penelitian Ariyati (2014) bahwa sikap masyarakat merupakan faktor protektif terhadap kejadian DBD dan kondisi lingkungan memiliki hubungan yang signifikan terhadap kejadian DBD. Nugroho (2009) menyatakan bahwa pelaksanaan pemberantasan sarang nyamuk yang buruk menunjukkan adanya hubungan positif dengan keberadaan jentik Aedes sp.

\section{KESIMPULAN}

Berdasarkan hasil penelitian dapat disimpulkan bahwa jenis tempat penampungan air terkontrol yang paling berpotensi sebagai tempat perindukan nyamuk dan paling banyak ditemukan larva Aedes sp. adalah bak mandi, sedangkan jenis tempat penampungan air yang sudah tidak terkontrol yang paling berpotensi sebagai tempat perindukan nyamuk dan paling banyak ditemukan larva Aedes sp. adalah kolam ikan bekas yang sudah tidak terdapat ikan di dalamnya. Jenis larva yang ditemukan pada berbagai tempat penampungan air di Kecamatan Metro Timur ada 2 jenis yaitu, larva Aedes aegypti dengan persentase $47,7 \%$ dan larva Aedes albopictus dengan persentase $52,3 \%$. Status maya index di Kecamatan Metro Timur masuk ke dalam kategori sedang.

\section{DAFTAR PUSTAKA}

Badrah, S., dan Hidayah, N. (2011). Hubungan antara tempat perindukan nyamuk Aedes aegypti dengan kasus demam berdarah dengue di Kelurahan Penajam Kecamatan Penajam Kabupaten Penajam Paser Utara. Journal of Tropical Pharmacy and Chemistry, 1(2), 153-160.

Dewantara, P. W. (2012). Analisis Resiko dengue berbasis Maya index pada rumah penderita DBD di Kota Banjar tahun 2012. Balaba, 11(1), 1-8.

Dinas Kesehatan Kota Metro. (2015). Profil Kesehatan Tahun 2015. Metro.

Kesehatan Tahun 2016. Metro.

Ditjen PP \& PL. (2008). Kunci Identifikasi Nyamuk Aedes. Jakarta.

Joharina, A. dan Widianti. (2014). Kepadatan larva nyamuk vektor sebagai indikator penularan demam berdarah dengue di daerah endemis di Jawa Timur: Jurnal Vektor Penyakit, 8(2), 3340. 
Nahla, K., Al-bar, A., Mohamed, K., AlFakeeh, (2009). A. knowledge, attitudes and practices relating to dengue faver among females in jeddah high schools. Journal Info Public Health, 2,30-40.

Nugroho, F. S. (2009). Faktor-faktor yang berhubungan dengan keberadaan jentik Aedes aegypti di RW IV Desa Ketitang Kecamatan Nogosari Kabupaten Boyolali. Universitas Muhamadiyah Surakarta. [Skripsi].

Purnama, S. G., Baskoro, T. (2012). Maya Index dan Kepadatan Larva Aedes aegypti terhadap Infeksi Dengue. . Denpasar: MAKARA Kesehatan.

Natadisastra, D., dan Agoes, R. (2009). Parasitologi Kedokteran Ditinjau dari Organ Tubuh yang Diserang. Jakarta: EGC.
Satoto, T.B.T. (2005). Penting Survey Jentik Sebelum Fogging. Medika, XXXI, 185.

Supartha. (2008) . Pengendalian Terpadu Vektor Virus Demam Berdarah Dengue, Aedes aegypti (Linn.) dan Aedes Albopictus (Skuse)(Diptera: Culicidae). . Denpasar: Universitas Udayana.

WHO. (2009). Panduan lengkap Pencegahan dan pengendalian Dengue dan Demam Berdarah Dengue. Jakarta: EGC.

Yotopranoto, S., Sri Subekti, Rosmanida, Salamun. (1998). Analisis dinamika populasi vektor pada lokasi dengan kasus demam berdarah dengue yang tinggi di Kotamadya Surabaya. Majalah Kedokteran Tropis Indonesia. 9, 23-31. 